\title{
TINGKAT KESUBURAN DAN REKOMENDASI PEMUPUKAN N, P, DAN K TANAH SAWAH KABUPATEN BENGKULU SELATAN
}

\author{
Nurmegawati, W. Wibawa, E.Makruf, D. Sugandi, dan T. Rahman \\ Balai Pengkajian Teknologi Pertanian Bengkulu \\ Jl Irian km 6,5 Kota Bengkulu
}

\begin{abstract}
An altematif way to detemine soil fertility level as well as to recommend fertilizer application is by using soil test kit. The kit can measure $P$ and $\mathrm{K}$ status of soils as well as the pH value. The research was aimed to evaluate soil fertility level of paddy soil and to determine fertilizer recommendation for rice (variety $\approx$ IR64) having $5 \mathrm{t}$ mill-dry seeds/ha at the soil in Kedurang Ilir and Seginim, South Bengkulu. Soil samples were collected in 24 villages in the area, then they were analyzed using the Test Kit. The results showed that (1) fertility level of paddy soil in Seginim was higher than that in Kedurang Ilir, (2) there were 4 packages of fertilizer doses (250- 100-100; 200-75-100; 250-50-100; 200-100-100 kg/ha for Urea-SP36$\mathrm{KCl}$, respectively) recommended in Kedurang Ilir, (3) there were 7 packages of fertilizer doses (250-100-100; 200-50-100; 250-75-100; 200-100-75; 200-75-100; 200-100-100; 250-50-100 $\mathrm{kg} / \mathrm{ha}$ for Urea, SP36, and KCl, respectively) in Seginim.
\end{abstract}

Key Words: paddy soil, fertility, soil test kit

\section{PENDAHULUAN}

Kabupaten Bengkulu Selatan mempunyai luas wilayah 118,610 ha. Sektor pertanian masih memberikan sumbangan paling besar yaitu $33.86 \%$, dengan luas lahan sawah 11.026 ha. Pada tahun 2010 terjadi peningkatan produksi padi di Kabupaten Bengkulu Selatan sebesar 3613,49 t dari $58.931,58$ t meningkat menjadi $62.545,07$ t. jika dibanding dengan tahun 2009. Atau setara dengan produksi beras 35.576,63 t (BPS Bengkulu Selatan, 2009). Jika dihubungkan dengan luas lahan sawahnya maka produktivitasnya masih rendah yang disebabkan oleh rendahnya tingkat kesuburan tanah dan belum tersedianya rekomendasi pemupukan spesifik lokasi.

Padi sawah merupakan konsumen pupuk terbesar di Indonesia. Efisiensi pemupukan tidak hanya berperan penting dalam meningkatkan pendapatan petani, tetapi juga terkait dengan keberlanjutan sistem produksi (sustainable production system), kelestarian lingkungan, dan penghematan sumberdaya energi. Kebutuhan dan efisiensi pemupukan ditentukan oleh dua faktor yang saling berkaitan yaitu: (a) ketersediaan hara dalam tanah, termasuk pasokan melalui air irigasi dan sumber lainnya, dan (b) kebutuhan hara tanaman. Oleh sebab itu, rekomendasi pemupukan harus bersifat spesifik lokasi dan spesifik varietas.

Sebenarnya banyak cara dan metode yang dapat digunakan dalam menentukan tingkat kesuburan tanah dan rekomendasi pemupukan N, P, dan K. Badan Litbang Pertanian bekerja sama dengan berbagai lembaga intemasional dan nasional seperti Intemational Rice Research Institute (IRRI), Lembaga Pupuk Indonesia, dan produsen pupuk telah menghasilkan dan mengembangkan beberapa metode dan alat bantu peningkatan efisiensi pemupukan $N, P$, dan K untuk tanaman padi sawah. Salah satunya dengan menggunkan Perangkat Uji Tanah Sawah (Departemen Pertanian, 2007). Menurut Setyorini, Widowati, Kasno. (2006) Perangkat Uji Tanah Sawah (PUTS) merupakan alat untuk mengukur status hara $\mathrm{P}$ dan $\mathrm{K}$ serta $\mathrm{pH}$ tanah yang dapat dikerjakan oleh penyuluh lapangan atau petani secara langsung di lapangan. Hasil analisis $P$ dan $K$ tanah dengan PUTS ini selanjutnya digunakan sebagai dasar penyusunan rekomendasi pupuk $\mathbf{P}$ dan $\mathrm{K}$ spesifik lokasi untuk tanaman padi sawah, terutama varietas unggul dengan 
produktivitas setara dengan IR-64 atau Ciherang.

Rekomendasi pemupukan adalah suatu rancangan yang meliputi jenis dan takaran pupuk untuk tanaman pada areal tertentu. Menurut Abdulrahman, Suhartatik, Kasno dan Setyorini (2008) banyak manfaat dan dampak penerapan pemupukan spesifik lokasi antara lain : (1) pemberian pupuk yang tepat takaran, tepat waktu dan jenis pupuk yang diperlukan sesuai maka pemupukan akan lebih efisien, hasil tinggi dan pendapatan petani meningkat, (2) pencemaran lingkungan dapat dihindari, kesuburan tanah tetap terjaga dan produksi padi lestari atau berkelanjutan, mengurangi biaya pembelian pupuk.

Tujuan dari penelitian ini adalah untuk mengetahui tingkat kesuburan dan membuat rekomendasi pemupukan padi sawah varietas setara IR-64 atau mempunyai potensi hasil 5 t GKG/ha.

\section{METODE PENELITIAN}

Penelitian ini dilaksanakan selama 4 bulan dari bulan Agustus sampai November 2011 di Kabupaten Bengkulu Selatan pada kecamatan Kedurang Ilir dan Seginim, yang meliputi 2 kegiatan utama yaitu pengambilan sampel dan mengukur tingkat kesuburan tanah dengan menggunakan PUTS. Menurut Abdulrahman, et al (2008) prinsip kerja PUTS yaitu mengukur hara $P$ dan $K$ tanah dalam bentuk tersedia dengan metode kolorimetri (pewarnaan), hasil analisis tersebut selanjutnya digunakan sebagai dasar penentuan rekomendasi pemupukan spesifik lokasi untuk tanaman padi sawah.

Pengambilan sampel tanah sawah dan pengukuran tingkat kesuburan tanah dilakukan di 2 kecamatan yaitu Kecamatan Seginim dan Kedurang Ilir yang dapat dilihat pada Tabel 1.

Tabel 1. Jumlah sampel tanah yang diambil per desa di Kecamatan Kedurang Ilir dan Seginim

\begin{tabular}{|c|c|c|c|}
\hline No & Kecamatan & Nama Desa & Jumlah sampel tanah \\
\hline 1. & & Lubuk Ladung & $\mathbf{1}$ \\
\hline 2. & & Nanjungan & 1 \\
\hline 3. & & Penindaian & 1 \\
\hline 4. & & Padang Bindu & \\
\hline 5. & Kedurang Ilir & Sukajaya & 1 \\
\hline 6. & & Air Sulau & 1 \\
\hline 7. & & Betungan & $\mathbf{1}$ \\
\hline 8. & & Kayu Kunyit & $\mathbf{1}$ \\
\hline 9. & & Pagar Banyu & $\mathbf{1}$ \\
\hline 10 & & Banding Agung & $\mathbf{1}$ \\
\hline 11. & & Pajar Bulan & 1 \\
\hline 12. & & Darat Sawah & 1 \\
\hline 13. & & Babatan Ulu & $\mathbf{1}$ \\
\hline 14. & & Muara Danau & 1 \\
\hline 15. & & Dusun Baru & 1 \\
\hline 16. & & Tanjung Agung & 1 \\
\hline 17. & Seginim & Babatan Illir & $\mathbf{1}$ \\
\hline 18. & & Gunung Ayu & 1 \\
\hline 19. & & Muara Payang & 1 \\
\hline 20. & & Darat Sawah Ulu & 1 \\
\hline 21. & & Tanjung Menang & $\mathbf{1}$ \\
\hline 22. & & Kota Agung & 1 \\
\hline 23. & & Padang Lebar & 1 \\
\hline 24. & & Durian Seginim & 1 \\
\hline
\end{tabular}


Alat yang digunakan dalam pengambilan sampel tanah yaitu (1)Bor tanah (auger, tabung), cangkul, atau sekop (2) Ember plastik untuk mengaduk kumpulan contoh tanah individu, (3). Alat suntik (syringe)Cara pengambilan contoh tanah komposit menurut Setyorini, et al (2006) adalah sebagai berikut : (1)Tentukan titik pengambilan contoh tanah individu dengan salah satu dari empat cara, yaitu secara diagonal, zig-zag, sistematik atau acak, (2) Contoh tanah sebaiknya diambil dalam keadaan lembab, tidak terlalu basah atau kering, (3) contoh tanah individu diambil dengan bor tanah, cangkul, atau sekop pada kedalaman 0-20 cm, (4) contoh tanah diaduk merata dalam ember plastik, (5) Contoh tanah lembab yang sudah siap untuk dianalisis diambil dengan syringe dengan cara: (1) permukaan tanah lembab ditusuk dengan syringe sedalam $5 \mathrm{~cm}$ dan diangkat, (2) bersihkan dan ratakan permukaan syringe, didorong keluar dan potong contoh tanah setebal sekitar $0,5 \mathrm{~cm}$ dengan sendok stainless, lalu masukkan ke dalam tabung reaksi.

Menurut Setyorini, et al (2006) secara garis besar urutan pengukuran kadar hara dengan PUTS adalah sebagai berikut: (a) Contoh tanah sebanyak $0,5 \mathrm{~g} \quad(0,5 \mathrm{ml})$ dengan syringe dimasukkan ke dalam tabung reaksi, (b) ditambahkan pengekstrak kemudian diaduk dengan pengaduk kaca hingga tanah dan larutan menyatu. Kemudian ditambah pengekstrak sesuai dengan urutannya, (c) diamkan larutan sekitar \pm 10 menit hingga timbul wama. Warna yang muncul pada larutan jemih dibaca atau dipadankan dengan bagan warna yang disediakan, (d) status hara $\mathbf{P}$ dan $\mathrm{K}$ tanah terbagi menjadi tiga kelas yaitu rendah, sedang, dan tinggi. Untuk hara $P$ diindikasikan oleh wama biru muda hingga biru tua, sedangkan untuk hara $K$ diindikasikan oleh warna coklat tua, coklat muda, dan kuning, (e) rekomendasi pemupukan $P$ dan $K$ ditentukan berdasarkan statusnya, (f) penentuan $\mathrm{pH}$ tanah dan rekomendasi teknologi didasarkan kepada kelas pH yang disetarakan dengan bagan warna.

\section{Status Hara Tanah Sawah}

Menurut Nyakpa, Lubis, Pulung, Amrah, Munawar, Hong, Hakim. (1988) setiap tanaman memerlukan paling sedikit 16 unsur agar petumbuhannya normal. Dari ke-16 unsur tersebut 3 unsur diperoleh dari udara dan 13 unsur disediakan tanah. Unsur yang disediakan tanah diantaranya unsur $\mathbf{N}$, $P$ dan K. Ketiga unsur tersebut amat terbatas jumlahnya dalam tanah. Hal ini disebabkan tanahnya miskin hara atau telah tersedot oleh tanaman.

Hasil analisis tanah dengan PUTS diperoleh status hara tanah sawah per desa di Kecamatan Kedurang Ilir dan Seginim (Tabel 2). Dari Tabel tersebut dapat dilihat kandungan $\mathbf{N}, \quad \mathbf{P}, \quad \mathrm{K}$ dan tingkat kemasamannya. Unsur hara $\mathbf{N}, P$ dan $K$ termasuk unsur hara makmo yang dibutuhkan dalam jumlah banyak dan mutlak harus ada. Peranan utama unsur $\mathbf{N}$ bagi tanaman adalah untuk merangsang pertumbuhan secara keseluruhan, khususnya batang, cabang dan daun. Selain itu, $\mathbf{N}$ berperan penting dalam pembentukan hijau daun yang sangat berfungsi dalam proses fotosintesis. Unsur P bagi tanaman berguna untuk merangsang pertumbuhan akar, khususnya akar benih dan tanaman muda serta mempercepat pembungaan, pemasakan biji dan buah. Unsur $K$ berfungsi membantu pembentukan protein dan karbohidrat dan juga berperan dalam memperkuat tubuh tanaman agar daun, bunga dan buah tidak mudah gugur. Unsur $K$ juga merupakan sumber kekuatan bagi tanaman dalam menghadapi kekeringan dan penyakit (Lingga dan Marsono 1999).

Berdasarkan hasil analisis N, P dan K tanah, di Kecamatan Kedurang Ilir kadar N pada umumnya tergolong rendah kecuali desa Nanjungan dan desa Kayu Kunyit masing-masing tergolong sedang dan tinggi. Kadar P umumnya tergolong rendah kecuali desa Nanjungan tergolong sedang dan desa Pagar Banyu tergolong tinggi. Kadar K pada masing-masing desa tergolong rendah sedangkan pH tanah sawah tergolong agak masam kecuali Desa Kayu Kunyit tergolong masam.

\section{HASIL DAN PEMBAHASAN}


Tabel 2. Status hara N, P dan K pada tanah sawah Kabupaten Bengkulu Selatan

\begin{tabular}{lllllll}
\hline No & Kecamatan & Nama Desa & Hasil Pengujian & \\
\cline { 3 - 6 } 1. & & N & P & K & pH \\
2. & Lubuk Ladung & Rendah & Rendah & Rendah & Agak masam \\
3. & Nanjungan & Sedang & Sedang & Rendah & Agak masam \\
4. & Kedurang & Penindaian & Rendah & Rendah & Rendah & Agak masam \\
5. & Sukajaya & Rir & Rendah & Rendah & Rendah & Agak masam \\
6. & Rendah & Rendah & Agak masam \\
7. & Air Sulau & Rendah & Rendah & Rendah & Agak masam \\
8. & Betungan & Rendah & Rendah & Rendah & Agak masam \\
9. & Kayu Kunyit & Tinggi & Rendah & Rendah & Masam \\
\hline 10 & Pagar Banyu & Rendah & Tinggi & Rendah & Agak masam \\
11. & Banding Agung & Rendah & Rendah & Rendah & Agak masam \\
12. & Pajar Bulan & Tinggi & Tinggi & Rendah & Agak masam \\
13. & Darat Sawah & Rendah & Sedang & Rendah & Agak masam \\
14. & Babatan Ulu & Rendah & Rendah & Rendah & Agak masam \\
15. & Muara Danau & Rendah & Tinggi & Rendah & Agak masam \\
16. & Dusun Baru & Tinggi & Tinggi & Rendah & Masam \\
17. & Seginim & Tanjung Agung & Sedang & Rendah & Sedang & Agak masam \\
18. & Babatan Ilir & Rendah & Tinggi & Rendah & Masam \\
19. & Gunung Ayu & Tinggi & Sedang & Rendah & Masam \\
20. & Muara Payang & Rendah & Rendah & Rendah & Agak masam \\
21. & Darat Sawah Ulu & Rendah & Sedang & Rendah & Agak masam \\
22. & Tanjung Menang & Rendah & Sedang & Rendah & Agak masam \\
23. & Kota Agung & Rendah & Rendah & Rendah & Agak masam \\
24. & Padang Lebar & Tinggi & Rendah & Rendah & Agak masam \\
\hline & Durian Seginim & Rendah & Tinggi & Rendah & Agak masam \\
\hline & & & & & \\
\hline
\end{tabular}

Secara umum kesuburan tanah sawah di desa-desa Kecamatan Seginim relatif beragam. Dari 17 desa yang diuji menunjukkan bahwa kadar $\mathbf{N}$ pada Kecamatan ini $70 \%$ tergolong rendah, hal ini disebabkan kebiasaan petani kurang dalam penambahan pupuk N. Disamping itu, tanaman padi sangat respon terhadap pupuk $\mathbf{N}$ dan butuh $\mathbf{N}$ lebih banyak dalam pertumbuhannya. Sebagian $\mathbf{N}$ dapat hilang terangkut panen dan pencucian. Selain itu, penambahan bahan organik yang jarang dilakukan menyebabkan kadar $\mathrm{N}$ tanah rendah, bahwa bahan organik merupakan salah satu sumber dari unsur hara salah satunya nitrogen.

Nyakpa et al (1988) menjelaskan bahwa dalam dekomposisi bahan organik $\mathbf{N}$ organik akan mengalami mineralisasi sedangkan $\mathbf{N}$ mineral mengalami imobolisasi. Sebagian $\mathbf{N}$ terangkut panen, sebagian kembali sebagai residu tanaman, hilang ke atmosfir dan kembali lagi, hilang melalui pencucian. Setyorini, et al (2006) menerangkan bahwa $\mathbf{N}$ yang dikandung tanah pada umumnya rendah, sehingga harus selalu ditambahkan dalam bentuk pupuk atau sumber lainnya pada setiap awal pertanaman. Selain kadarnya rendah, $\mathbf{N}$ dalam tanah mempunyai sifatnya yang dinamis dan mudah hilang menguap dan tercuci bersama air drainase.

Untuk Kadar $P$ tanah pada umumnya tergolong rendah, hal ini disebabkan kebiasaan petani yang kurang bahkan tidak menambahkan pupuk $P$ pada saat tanam padi dan tidak adanya pengembalian bahan organik ke tanah. Kehilangan unsur $\mathbf{P}$ pada saat terangkut panen, merupakan jumlah hara tanaman yang hilang karena diserap tanaman dan dipengaruhi oleh produksi yang dihasilkan. Semakin tinggi produksi maka unsur hara yang diserap tanaman semakin banyak pula sehingga akan mengurangi kandungan unsur hara yang ada dalam tanah.

Kadar K di kedua kecamatan ini tergolong rendah, karena kebiasaan petani 
dalam pemberian pupuk kurang dan tidak adanya pengembalian jerami ke tanah. Unsur $K$ dapat juga hilang terangkut panen dan sifatnya yang mobile (mudah bergerak) sehingga mudah hilang melalui proses pencucian . Nyakpa, et al (1988) menerangkan bahwa kehilangan $K$ pada tanah pertanian intensif cukup besar melalui bentuk pencucian dan erosi. Di samping itu juga Setyorini, et al (2006) menerangkan bahwa pada tanaman padi, sebagian dari hara $\mathrm{K}$ dapat digantikan oleh jerami padi, kadar K dalam jerami umumnya sekitar $1 \%$ sehingga dalam 50 ton jerami terdapat 50 kg K setara dengan pemupukan $50 \quad \mathrm{~kg}$ $\mathrm{KCl} /$ ha. Rosmarkam dan Yunowo (2002) menyatakan bahwa penyerapan $\mathbf{P}$ di jerami lebih besar dari pada di bijinya.

Keadaan unsur hara dalam tanah dipengaruhi oleh beberapa faktor, antara lain : kecepatan pelapukan mineral tanah, sifat bahan induk, keadaan tanaman yang hidup di atasnya, dan laju pencucian oleh air hujan. Jika laju pencucian unsur sangat besar dan intensitas pelapukan rendah, maka kehidupan unsur hara lebih besar dibandingkan dengan pengambilan unsur hara oleh tanaman. Ini berarti proses pemiskinan tanah (Rosmarkam dan Yunowo 2002).

Reaksi tanah, yang dinyatakan dengan pH, menunjukkan tingkat kemasaman tanah. Pada Kecamatan Kedurang Ilir maupun Seginim pada umumnya tergolong agak masam. Hal ini tidak menjadi masalah karena jika tanah mineral disawahkan (digenangi), maka pH tanah akan mengarah ke netral atau dengan kata lain tanah awal yang masam pH-nya akan meningkat. Sebaliknya tanah awal yang alkalin, pH-nya akan turun menuju pH netral.

\section{Rekomendasi Pemupukan}

Dari data status hara tanah sawah di Kabupaten Bengkulu Selatan maka dipenoleh rekomendasi pupuk $\mathbf{N}, \mathbf{P}$ dan $\mathrm{K}$ dalam bentuk Urea, SP-36 dan KCl untuk padi sawah setara IR-64 atau yang mempunyai potensi hasil 5 t GKG/ha. Urea termasuk pupuk $\mathbf{N}$ yang dibuat dari gas amoniak dan gas asam, mengandung $46 \% \mathrm{~N}$ dan hidroskopis. Oleh karena itu pupuk Urea mudah larut dalam air dan mudah diserap tanaman. SP-36 merupakan pupuk $P$ yang mengandung $36 \% \mathrm{P}_{2} \mathrm{O}_{5}$ sedangkan pupuk $\mathrm{K}$ adalah pupuk Kaliumclorida (KCl) yang memiliki kadar $\mathrm{K}_{2} \mathrm{O} 60$ - $62 \%$. Pada Tabel 3 disajikan rekomendasi pemupukan padi sawah tingkat desa pada Kecamatan Kedurang Ilir dan Kecamatan Seginim Kabupaten Bengkulu Selatan.

Rekomendasi pupuk untuk padi sawah di Kecamatan Kedurang Ilir relatif sama yaitu Urea $250 \mathrm{~kg} / \mathrm{ha}$, SP-36 $100 \mathrm{~kg} / \mathrm{ha}$ dan $\mathrm{KCl} 100 \mathrm{~kg} / \mathrm{ha}$ kecuali desa Nanjungan dengan rekomendasi Urea $200 \mathrm{~kg} / \mathrm{ha}, \mathrm{SP}-36$ 75 kg/ha, KCl 100 kg/ha, desa Pagar Banyu memiliki rekomendasi Urea $250 \mathrm{~kg} / \mathrm{ha}$, SP$3650 \mathrm{~kg} / \mathrm{ha}, \mathrm{KCl} 100 \mathrm{~kg} / \mathrm{ha}$ dan desa Kayu Kunyit dengan rekomendasinya $200 \mathrm{~kg} / \mathrm{ha}$ Urea, 100 kg/ha SP-36, 100 kg/ha KCl.

Untuk Kecamatan Seginim memiliki rekomendasi pupuk yang relatif beragam. Dari 15 desa yang diuji terdapat 6 macam rekomendasi pupuk yaitu (1) $250 \mathrm{~kg} / \mathrm{ha}$ Urea, $100 \mathrm{~kg} / \mathrm{ha} \mathrm{SP-36}$ dan $100 \mathrm{~kg} / \mathrm{ha} \mathrm{KCl}$ untuk desa Banding Agung, Babatan Ulu, Muara Payang dan Kota Agung, (2) $200 \mathrm{~kg} / \mathrm{ha}$ Urea, $50 \mathrm{~kg} / \mathrm{ha}$ SP-36 dan $100 \mathrm{~kg} / \mathrm{ha} \mathrm{KCl}$ untuk desa Pajar Bulan, Muara Danau, Dusun Baru dan Babatan Ilir (3) $250 \mathrm{~kg} / \mathrm{ha}$ Urea, 75 kg/ha SP-36 dan $100 \mathrm{~kg} / \mathrm{ha} \mathrm{KCl}$ untuk Desa Darat Sawah, Darat Sawah Ulu, Tanjung Menang (4) $200 \mathrm{~kg} / \mathrm{ha}$ Urea, 100 kg/ha SP-36 dan $75 \mathrm{~kg} / \mathrm{ha} \mathrm{KCl}$ untuk desa Tanjung Agung (5) $200 \mathrm{~kg} / \mathrm{ha}$ Urea, 75 kg/ha SP-36 dan $100 \mathrm{~kg} / \mathrm{ha} \mathrm{KCl}$ untuk desa Gunung Ayu. (6) 200 kg/ha Urea, $100 \mathrm{~kg} / \mathrm{ha}$ SP-36 dan $100 \mathrm{~kg} / \mathrm{ha} \mathrm{KCl}$ untuk desa Padang Lebar (7) 250 kg/ha Urea, 50 kg/ha SP-36 dan $100 \mathrm{~kg} / \mathrm{ha} \mathrm{KCl}$ untuk desa Durian Seginim.

Menurut Sofyan, et al dalam Mario, Zubair, Ahmad, Febrianti, Indah, Pakaya (2008) rekomendasi pemupukan $P$ dibuat berdasarkan filosofi sebagai berikut : (1) pada tanah yang berstatus $P$ tinggi, pemupukan $\mathbf{P}$ dimaksudkan hanya untuk memenuhi/mengganti $P$ yang diangkut oleh tanaman, (2) pada tanah berstatus $P$ sedang dan rendah pemberian pupuk $P$ di samping untuk mengganti $P$ yang terangkut oleh tanaman juga untuk meningkatkan kadar $\mathbf{P}$. Sedangkan menurut Puslittanak Mario, et al (2008) pada tanah yang berstatus $K$ rendah, 
Tabel 3. Rekomendasi pemupukan padi sawah Kecamatan Kedurang Ilir dan Seginim Kabupaten Bengkulu Selatan

\begin{tabular}{|c|c|c|c|c|c|}
\hline \multirow[t]{2}{*}{ No } & \multirow[t]{2}{*}{ Kecamatan } & \multirow[t]{2}{*}{ Nama Desa } & \multicolumn{3}{|c|}{ Rekomendasi (Kg/ha) } \\
\hline & & & Urea & SP-36 & $\mathrm{KCl}$ \\
\hline 1. & & Lubuk Ladung & 250 & 100 & 100 \\
\hline 2. & & Nanjungan & 200 & 75 & 100 \\
\hline 3. & & Penindaian & 250 & 100 & 100 \\
\hline 4. & & Padang Bindu & 250 & 100 & 100 \\
\hline 5. & Kedurang Ilir & Sukajaya & 250 & 100 & 100 \\
\hline 6. & & Air Sulau & 250 & 100 & 100 \\
\hline 7. & & Betungan & 250 & 100 & 100 \\
\hline 8. & & Kayu Kunyit & 200 & 100 & 100 \\
\hline 9. & & Padang Bayu & 250 & 50 & 100 \\
\hline 10. & & Banding Agung & 250 & 100 & 100 \\
\hline 11. & & Pajar Bulan & 200 & 50 & 100 \\
\hline 12. & & Darat Sawah & 250 & 75 & 100 \\
\hline 13. & & Babatan Ulu & 250 & 100 & 100 \\
\hline 14. & & Muara Danau & 200 & 50 & 100 \\
\hline 15. & & Dusun Baru & 200 & 50 & 100 \\
\hline 16. & & Tanjung Agung & 200 & 100 & 75 \\
\hline 17. & Seginim & Babatan Ilir & 200 & 50 & 100 \\
\hline 18. & & Gunung Ayu & 200 & 75 & 100 \\
\hline 19. & & Muara Payang & 250 & 100 & 100 \\
\hline 20. & & Darat Swah Ulu & 250 & 75 & 100 \\
\hline 21. & & Tanjung Menang & 250 & 75 & 100 \\
\hline 22. & & Kota Agung & 250 & 100 & 100 \\
\hline 23. & & Padang Lebar & 200 & 100 & 100 \\
\hline 24. & & Durian Seginim & 250 & 50 & 100 \\
\hline
\end{tabular}

kemungkinan untuk memperoleh respon pemupukan $\mathrm{K}$ cukup besar sedangkan tanah dengan status $K$ sedang dan tinggi tidak perlu diberi pupuk $\mathbf{K}$.

Pupuk majemuk adalah pupuk yang mengandung lebih dari satu jenis unsur hara utama. Pupuk majemuk yang beredar saat ini umumnya dalam bentuk NPK (Rosmarkam, 2002). Rekomendasi yang disusun dalam dari pupuk tunggal (Tabel 3) disetarakan dengan pupuk majemuk (Tabel 4).

Berdasarkan Tabel 4 rekomendasi pupuk majemuk dan pupuk tunggal pada Kecamatan Kedurang Ilir pada umumnya sama yaitu $240 \mathrm{~kg} / \mathrm{ha}$ NPK, $170 \mathrm{~kg} / \mathrm{ha}$ Urea $40 \mathrm{~kg} / \mathrm{ha} \mathrm{KCl}$, kecuali Desa Nanjungan, Kayu Kunyit dan Padang Banyu masingmasing rekomendasinya adalah $180 \mathrm{~kg} / \mathrm{ha}$ NPK, $140 \mathrm{~kg} / \mathrm{ha}$ Urea dan $55 \mathrm{~kg} / \mathrm{ha} \mathrm{KCl}$, $240 \mathrm{~kg} / \mathrm{ha}$ NPK $120 \mathrm{~kg} / \mathrm{ha}$ urea $40 \mathrm{~kg} / \mathrm{ha}$ KCl dan $120 \mathrm{~kg} / \mathrm{ha}$ NPK $210 \mathrm{~kg} / \mathrm{ha}$ Urea 70 kg/ha KCl.
Rekomendasi pupuk majemuk dan tunggal Kecamatan Seginim sangat beragam, pada kecamatan ini terbagi 7 rekomendasi yaitu (1) $240 \mathrm{~kg} / \mathrm{ha}$ NPK, 170 $\mathrm{kg} / \mathrm{ha}$ Urea dan $40 \mathrm{~kg} / \mathrm{ha} \mathrm{KCl}$ untuk Desa Banding Agung, Babatan Ulu, Muara Payang dan Kota Agung (2) $120 \mathrm{~kg} / \mathrm{ha}$ NPK, $160 \mathrm{~kg} / \mathrm{ha}$ Urea, $70 \mathrm{~kg} / \mathrm{ha} \mathrm{KCl}$ untuk Desa Pajar Bulan, Muara Danau, Dusun Baru dan Babatan Ilir (3) $180 \mathrm{~kg} / \mathrm{ha}$ NPK, $190 \mathrm{~kg} / \mathrm{ha}$ Urea dan $55 \mathrm{~kg} / \mathrm{ha} \mathrm{KCl}$ untuk Desa Darat Sawah, Darat Sawah Ulu, Tanjung Menang (4) $240 \mathrm{~kg} / \mathrm{ha}$ NPK, $120 \mathrm{~kg} / \mathrm{ha}$ Urea dan 10 $\mathrm{kg} / \mathrm{ha} \mathrm{KCl}$ untuk Desa Tanjung Agung (5) $180 \mathrm{~kg} / \mathrm{ha}$ NPK, $140 \mathrm{~kg} / \mathrm{ha}$ Urea dan 55 kg/ha KCl untuk Desa Gunung Ayu. (6) 240 kg/ha NPK, $120 \mathrm{~kg} / \mathrm{ha}$ Urea dan $40 \mathrm{~kg} / \mathrm{ha}$ KCl untuk Desa Padang Lebar (7) $120 \mathrm{~kg} / \mathrm{ha}$ NPK, $210 \mathrm{~kg} / \mathrm{ha}$ Urea dan $70 \mathrm{~kg} / \mathrm{ha} \mathrm{KCl}$ untuk Desa Durian Seginim. 
Tabel 4. Rekomendasi pemupukan padi sawah dengan menggunakan pupuk majemuk dan tunggal di Kabupaten Bengkulu Selatan

\begin{tabular}{|c|c|c|c|c|c|c|}
\hline \multirow[t]{2}{*}{ No } & \multirow[t]{2}{*}{ Kecamatan } & \multirow[t]{2}{*}{ Desa } & \multirow{2}{*}{$\begin{array}{c}\text { Pupuk } \\
\text { Majemuk } \\
\text { (kg/ha) }\end{array}$} & \multicolumn{3}{|c|}{ Tambahan pupuk tunggal Kg/ha) } \\
\hline & & & & Urea & SP-36 & KCl \\
\hline 1. & \multirow{9}{*}{$\begin{array}{l}\text { Kedurang } \\
\text { Ilir }\end{array}$} & Lubuk Ladung & 240 & 170 & $\mathbf{0}$ & 40 \\
\hline 2. & & Nanjungan & 180 & 140 & $\mathbf{0}$ & 55 \\
\hline 3. & & Penindaian & 240 & 170 & $\mathbf{0}$ & 40 \\
\hline 4. & & Padang Bindu & 240 & 170 & $\mathbf{0}$ & 40 \\
\hline 5. & & Sukajaya & 240 & 170 & 0 & 40 \\
\hline 6. & & Air Sulau & 240 & 170 & $\mathbf{0}$ & 40 \\
\hline 7. & & Betungan & 240 & 170 & $\mathbf{0}$ & 40 \\
\hline 8. & & Kayu Kunyit & 240 & 120 & $\mathbf{0}$ & 40 \\
\hline 9. & & Padang Banyu & 120 & 210 & $\mathbf{0}$ & 70 \\
\hline 10. & \multirow{15}{*}{ Seginim } & Banding Agung & 240 & 170 & $\mathbf{0}$ & 40 \\
\hline 11. & & Pajar Bulan & 120 & 160 & $\mathbf{0}$ & 70 \\
\hline 12. & & Darat Sawah & 180 & 190 & $\mathbf{0}$ & 55 \\
\hline 13. & & Babatan Ulu & 240 & 170 & $\mathbf{0}$ & 40 \\
\hline 14. & & Muara Danau & 120 & 160 & $\mathbf{0}$ & 70 \\
\hline 15. & & Dusun Baru & 120 & 160 & $\mathbf{0}$ & 70 \\
\hline 16. & & Tanjung Agung & 240 & 120 & $\mathbf{0}$ & 10 \\
\hline 17. & & Babatan Ilir & 120 & 160 & $\mathbf{0}$ & 70 \\
\hline 18. & & Gunung Ayu & 180 & 140 & $\mathbf{0}$ & 55 \\
\hline 19. & & Muara Payang & 240 & 170 & $\mathbf{0}$ & 40 \\
\hline 20. & & Darat Sawah Ulu & 180 & 190 & $\mathbf{0}$ & 55 \\
\hline 21. & & Tanjung Menang & 180 & 190 & $\mathbf{0}$ & 55 \\
\hline 22. & & Kota Agung & 240 & 170 & $\mathbf{0}$ & 40 \\
\hline 23. & & Padang Lebar & 240 & 120 & $\mathbf{0}$ & 40 \\
\hline 24. & & Durian Seginim & 120 & 210 & $\mathbf{0}$ & 70 \\
\hline
\end{tabular}

Rekomendasi pada Tabel 4, terlihat bahwa selain menggunakan pupuk majemuk NPK juga menggunakan pupuk tunggal benupa Urea dan KCl. Hal ini disebabkan di dalam pupuk NPK tersebut belum tencukupi kebutuhan hara $\mathbf{N}$ dan $\mathrm{K}$, tetapi kebutuhan hara $\mathbf{P}$ sudah terpenuhi. Setyorini, et al (2006), menyatakan bahwa penggunaan pupuk majemuk yang tidak tepat dosis menyebabkan kelebihan atau kekuranagan unsur tertentu (N, P atau K). Oleh karena itu aplikasi pupuk majemuk tetap memerlukan tambahan pupuk tunggal terutama $\mathrm{N}$.

\section{KESIMPULAN DAN SARAN}

Kesimpulan

1. Tingkat kesuburan tanah sawah di Kecamatan Seginim tergolong lebih subur dibanding dengan Kecamatan Kedurang Ilir.
2. Rekomendasi pemupukan dalam bentuk pupuk tunggal di Kecamatan Kedurang Ilir yaitu (1) $250 \mathrm{~kg} / \mathrm{ha}$ Urea, $100 \mathrm{~kg} / \mathrm{ha}$ SP-36 dan 100 $\mathrm{kg} / \mathrm{ha} \mathrm{KCl}$ untuk Desa Lubuk Ladung, Penindaian, Padang Bindu, Sukajaya, Air Sulau dan Betungan (2) $200 \mathrm{~kg} / \mathrm{ha}$ Urea, $75 \mathrm{~kg} / \mathrm{ha} S P-36$ dan $100 \mathrm{~kg} / \mathrm{ha} \mathrm{KCl}(3) \quad 250 \mathrm{~kg} / \mathrm{ha}$ Urea, $50 \mathrm{~kg} / \mathrm{ha}$ dan $100 \mathrm{~kg} / \mathrm{ha} \mathrm{KCl}$ untuk Pagar banyu (4) $200 \mathrm{~kg} / \mathrm{ha}$ Urea, $100 \mathrm{~kg} / \mathrm{ha} S P-36$ dan100 kg/ha KCl untuk Desa Kayu Kunyit.

3. Rekomendasi pemupukan pupuk tunggal Kecamatan Seginim yaitu (1) $250 \mathrm{~kg} / \mathrm{ha}$ Urea, $100 \mathrm{~kg} / \mathrm{ha} \mathrm{SP}-36$ dan $100 \mathrm{~kg} / \mathrm{ha} \mathrm{KCl}$ untuk desa Banding Agung, Babatan Ulu, Muara Payang dan Kota Agung (2) $200 \mathrm{~kg} / \mathrm{ha}$ Urea, $50 \mathrm{~kg} / \mathrm{ha} \mathrm{SP-36}$ dan $100 \mathrm{~kg} / \mathrm{ha} \mathrm{KCl}$ untuk desa Pajar Bulan, Muara Danau, Dusun Baru 
dan Babatan Ilir (3) $250 \mathrm{~kg} / \mathrm{ha}$ Urea , $75 \mathrm{~kg} / \mathrm{ha}$ SP-36 dan $100 \mathrm{~kg} / \mathrm{ha} \mathrm{KCl}$ untuk desa Darat Sawah, Darat Sawah Ulu, Tanjung Menang (4) $200 \mathrm{~kg} / \mathrm{ha}$ Urea, $100 \mathrm{~kg} / \mathrm{ha}$ SP-36 dan $75 \mathrm{~kg} / \mathrm{ha} \mathrm{KCl}$ untuk desa Tanjung Agung (5) $200 \mathrm{~kg} / \mathrm{ha}$ Urea, $75 \mathrm{~kg} / \mathrm{ha} \mathrm{SP-36}$ dan $100 \mathrm{~kg} / \mathrm{ha} \mathrm{KCl}$ untuk desa Gunung Ayu. (6) 200 $\mathrm{kg} / \mathrm{ha}$ Urea, $100 \mathrm{~kg} / \mathrm{ha}$ SP-36 dan $100 \mathrm{~kg} / \mathrm{ha} \mathrm{KCl} \mathrm{(7)} 250 \mathrm{~kg} / \mathrm{ha}$ Urea, $50 \mathrm{~kg} / \mathrm{ha}$ SP-36 dan $100 \mathrm{~kg} / \mathrm{ha} \mathrm{KCl}$ untuk desa Durian Seginim.

\section{Saran}

Jumlah sampel tanah yang diambil di setiap desa harus disesuaikan dengan luas sawah yang terdapat di wilayah tersebut.

\section{DAFTAR PUSTAKA}

Abdulrahman,S., Suhartatik,E., Kasno,A., dan Setyorini,D. 2008. Modul pemupukan padi sawah spesifik lokasi. Badan Penelitian dan Pengembangan Pertanian. Jakarta.

BPS. 2009. Bengkulu dalam angka. Badan Pusat Statistik. Bengkulu
Departemen Pertanian. 2007. Peraturan menteri pertanian Nomor 40/permentan/OT.140/04/2007 tanggal 11 April 2007 tentang rekomendasi pemupukan N, P dan K pada padi sawah spesifik lokasi. Jakarta.

Fahri, A. 2011. Pemupukan N, P dan K pada padi sawah tadah hujan. Prosiding seminar nasional tanaman pangan. Bogor

Lingga.P, Marsono. 1999. Petunjuk penggunaan pupuk. Penebar Swadaya. Jakarta

Mario,M.D.Zubair,A.Ahmad,A.Febrianti,T.I ndah,F.S.Pakaya,R. 2008. Rekomendasi pemupukan padi sawah spesifik lokasi. BPTP Gorontalo. Gorontalo.

Nyakpa, M.Y. A.M.Lubis, M.A. Pulung, A.G.Amrah, A.Munawar, G.B.Hong, N.Hakim. 1988. Kesuburan Tanah. Universitas Lampung. Lampung.

Rosmarkam, A. Yuwono.N.W. 2002. Ilmu Kesuburan Tanah. Kanisius. Yogyakarta

Setyorini, D. Widowati, L.R, Kasno, A. 2006. Petunjuk Penggunaan Perangkat Uji Tanah Sawah (PUTS). Balai Penelitian Tanah. Bogor 